\title{
Androgens in SARS-CoV-2 Coronavirus Infections
}

\author{
Luboslav STÁRKA ${ }^{1}$, Michaela DUŠKOVÁ ${ }^{1}$ \\ ${ }^{1}$ Institute of Endocrinology, Prague, Czech Republic
}

Received May 11, 2021

Accepted July 29, 2021

\section{Summary}

Recent molecular biology findings have shown that for the penetration of the SARS-CoV-2 coronavirus into host cells, a key role is played by protease serine 2 , the activity of which is dependent on androgens. The important role of androgens is also evidenced by clinical observations that men in some age categories are infected by this novel coronavirus up to two times more frequently than women. In addition, men with androgenic alopecia tend to have more serious clinical courses, while men with androgen deprivation as a result of prostate cancer treatments tend to have milder courses. This is in line with the fact that preadolescent children are only rarely sickened with serious forms of SARS-CoV-2 infections. Even though these observations may be explained by other factors, many authors have hypothesized that lowered androgen levels and blocking their activity using anti-androgen medication may moderate the course of the viral infection in intermediately- to critically-affected cases. Clearly, it would be important for androgen deprivation to block not just gonadal androgens, but also adrenal androgens. On the other hand, low androgen levels are considered to be a risk factor for the course of SARS-CoV-2 infections, either because low androgen levels have a general effect on anaboliccatabolic equilibrium and energy metabolism, or because of the ability of testosterone to modify the immune system. It is not yet clear if infection with this novel coronavirus might induce hypogonadism, leading to undesirable side effects on male fertility.

\section{Key words}

COVID-19 • Androgens • Adrenal androgens • Male fertility

\section{Corresponding author}

L. Stárka, Institute of Endocrinology, Národní 8, 11694 Praha 1, Czech Republic. E-mail: Istarka@endo.cz

\section{Introduction}

The current coronavirus disease COVID-19, caused by the severe acute respiratory syndrome coronavirus 2 (SARS-CoV-2), has evolved into a global pandemic affecting the worldwide population. Two notably consistent findings are the low rates of prepubertal mortality, and that men are more likely to have severe symptoms and need hospitalization. The genetic predisposition of the host (Vašků 2020) and the activity of the immune system (Pačes et al. 2020) both play important roles, but the endocrine system also affects the course of infections.

The first biological requirement for SARS-CoV-2 coronavirus infectivity, which mainly causes acute respiratory syndromes, is the penetration of the virus into the host cells, generally type II pneumocytes. This is a complex process in which endocrine factors are involved.

Hypotheses on the influence of androgens on the course of SARS-CoV-2 infections were first described by Montopoli et al. in May 2020 (Montopoli et al. 2020) almost simultaneously with the group in the USA (Goren et al. 2020a). Montopoli and colleagues arrived at this hypothesis based on data on the different courses of coronavirus infections in men with prostate cancer treated with androgen deprivation therapy or treated with other methods. The role of sex hormones in the course of COVID-19 became a hot topic, and by the end of 2020 over a hundred studies had been published on the influence of androgens on coronavirus infections. In addition to clinical observations, these hypotheses were based on the molecular biology of the penetration of SARS-CoV-2 into host cells. 


\section{The basic process of coronavirus infection}

A key step in coronavirus infection is the penetration of the virus into the host cells. Briefly, this can be described at the level of molecular biology as follows. The SARS-CoV-2 coronavirus enters the cell through receptors for angiotensin converting enzyme type 2 (ACE-2), which is expressed in pneumocytes. ACE-2 functions to metabolize angiotensin II to angiotensin variants with lower inflammatory activity. Angiotensin II binds to type 2 angiotensin receptors (AT1Rs), leading to the induction of pulmonary vasoconstriction and inflammation modulated by nuclear factor $\mathrm{\kappa B}$ (NF- $\mathrm{\kappa B})$. This pathway increases the production of cytokines. Low levels of the conversion enzyme ACE-2 and high levels of angiotensin II result in the increased permeability of pulmonary veins and inflammatory damage to lung tissue (Gurwitz et al. 2020). The reason for lung damage during more severe SARS-CoV-2 infection stages is therefore currently thought to be from a cytokine storm resulting from a non-controlled immune response to lung damage (Shi et al. 2020, Al-Lami et al. 2020). The primary modulator at the beginning of this process is angiotensin II.

For viral attachment to the cell surface, proteolysis made possible by transmembrane protease serine 2 (TMPRSS2) is also necessary (Hoffmann et al. 2020). This protease allows the virus to bind to the ACE-2 receptor, and is considered necessary for SARS-CoV-2 coronavirus infection (Wambier and Goren 2020). Transcription of the TMPRSS2 gene is likely dependent on androgen receptors, and androgens are a pro-motor for this gene (Lucas et al. 2014). Factors that regulate angiotensin II levels therefore include not just those known from studies on the renin-angiotensinaldosterone axis, but also androgens.

In addition, androgens also play other roles influencing the course of SARS-CoV-2 infections, such as suppressing the immune system, as well as effects on overall organism resilience and anabolic-catabolic equilibrium, on the cardiovascular system, and on metabolism in general.

\section{Observations of the negative role of androgens on SARS-CoV-2 coronavirus infections}

\section{Risks of higher androgen levels}

The first study to hypothesize that androgens may play a negative role in more severe cases of SARSCoV-2 infections was a report (Montopoli et al. 2020) on observations of differences in patients with prostate cancer treated by androgen deprivation and those treated with other methods. This observation was supported by other authors (John and Kestner 2020, Cattrini et al. 2020, McCoy et al. 2020), though still other authors reported no such affect (Klein et al. 2021).

Worldwide statistics show that males are more likely to be victims of SARS-CoV-2 coronavirus infections (Giagulli et al. 2020, Cattrini et al. 2020, Wadman 2020) and that pre-pubertal children are possible carriers of the infection, but their course is largely asymptomatic. While these facts may be explained by reasons other than the hormonal environment (Al-Lami et al. 2020, Karlberg et al. 2004, Wenham et al. 2020), other findings indicate that androgens have a negative role in the course of coronavirus infection (Wadman 2020), not only in men but also in women with signs of hyperandrogenemia, such as those with polycystic ovary syndrome (Cadegieni et al. 2020b). Clinical observations have also shown a higher proportion of men with androgenic alopecia (AGA) among infected men than in the general population. AGA is thought to result from the action of dihydrotestosterone, the most potent androgen, on the hair follicles of the scalp (Wambier et al. 2020a,b,c, Goren et al. 2020a,b, Goren et al. 2021).

A relatively common cause of hyperandrogenization in younger individuals is anabolic steroid abuse. However, there is still a lack of information in the literature about the effect of anabolic-androgenic doping on the course of COVID-19. Another indicator of androgenization, in this case temporally localized to fetal development, is thought to be the index finger to ring finger ratio. A high mean 2D:4D ratio indicates prenatal low testosterone/high estradiol ratio. On the basis of a study on more than 180000 men and women, Manning and Fink (2020) speculated that this ratio is associated with high case fatality rates and male mortality in coronavirus infection. However, a robust Bayesian analysis (Jones et al. 2021) of the data could not confirm this hypothesis.

In assessing the effect of androgens on SARSCoV-2 infections, the involvement of adrenal androgens has not yet been taken into account, as they represent a small proportion of total androgens (Stárka et al. 2020b) and may change during the course of the disease, especially when dexamethasone or other corticosteroids are used. 
Risks of low androgen levels

Hypotheses on the risk of higher androgen levels on the course of SARS are not supported, however, by other observations on the course of the disease and its mortality. On the contrary low total or free testosterone was reported as a risk. Less positive course of the disease was recorded in androgen deficient patients with testosterone levels below $5 \mathrm{nmol} / \mathrm{l}$ (Rowland and O'Brien Bergin 2020), in patients who needed testosterone replacement therapy (Rambhatla et al. 2021, La Vignera et al. 2020), or in association with the relatively frequent low testosterone in patients with COVID-19 pneumonia or other lung diseases (Pozzilli and Lenzi 2020).

It has been assumed that testosterone, in comparison to estrogen, may predispose men to widespread COVID-19 infections. Low serum testosterone levels, which may be supposed to characterize the hormonal milieu in seriously ill individuals, may predispose men, especially elderly men, to poor prognosis or death (Giagulli et al. 2021).

Decreased testosterone levels in critically ill men negatively affect endothelial cell function, lead to immune response disorders and less effective removal of the virus from the body, and contribute to systemic inflammation. Low testosterone could be a prognostic indicator of an adverse course of COVID-19 (Hussein et al. 2020).

Low testosterone levels also predicted clinical adverse outcomes in a study on a consecutive series of 31 male patients affected by SARS-CoV-2 pneumonia and recovered in the respiratory intensive care unit (Rasterlli et al. 2021). The study demonstrated that lower baseline levels of total testosterone and free testosterone levels predicted poor prognoses and mortality in SARS-CoV-2infected men. Significantly lower testosterone levels and higher LH and prolactin were also found in patients with COVID-19 pneumonia by other authors (Okçelik 2021, Kadihasanoglu et al. 2021). On the contrary, a study in Asia (Xu et al. 2021) concluded that in males infected with SARS-CoV-2, most sex-related hormones (testosterone, FSH and LH levels) remain within the normal reference ranges after recovery, and no significant associations were observed between testosterone level and disease duration or severity. At present, there is insufficient evidence to show that SARS-CoV-2 causes hypogonadism and sterility, but the potential risk should not be ignored. Papadopoulos et al. (2021) came to a similar conclusion: it is not known whether low testosterone levels in aging hypogonadal males create a permissive environment for severe responses to COVID-19 infection or if the virus inhibits androgen formation.

The question has also been raised whether supplementation of low testosterone levels with androgen therapy alters the risk of SARS-coV-2 infections (Rambhatla et al. 2021, La Vignera et al. 2020). According to the findings by Rambhatla et al. 2021, there were no statistically significant differences between hypogonadal men that were not treated, and those on testosterone replacement therapy.

Regarding androgen levels, it should also be pointed out that the majority of patients with SARS-CoV-2 infection in intensive care units are obese men. In overweight and obese men in particular, we generally find lower concentrations of circulating total testosterone, but free and bioavailable testosterone tend to be within reference ranges (Stárka et al. 2020a). Indeed these latter two, and not total levels, are relevant to the role of testosterone in the body.

In considering the dual effect of testosterone in pulmonary viral infections, i.e. the adverse effects of both low and normal testosterone concentrations, some authors (Kezele 2020, Hussain et al. 2020, Pozzilli et al. 2020, Al-Lehmi et al. 2020) have concluded that these effects are not mutually exclusive and that they may depend on the stage of the disease. It is certainly justified to imagine different roles of sex hormones in different stages of the immune response via Th1 lymphocytes and the body's cellular response to toxins or in the stimulation of antibody production by $\mathrm{Th} 2$ lymphocytes.

\section{SARS-CoV-2 coronavirus infections and male fertility}

There are a number of hypotheses that suggest that COVID-19 could affect male fertility as an immediate or long-term consequence of the disease. One important finding is that the angiotensin converting enzyme 2 (ACE2) receptor, which aids the entry of SARS-CoV-2 into host cells, is highly expressed in testicular Sertoli and Leydig cells as well as in spermatozoa. Moreover, SARS-CoV-2 infection-induced uncontrolled inflammatory responses may lead to systemic oxidative stress, whose severe disruptive effects on testicular function are well documented (Dutta and Sengupta 2021). Consequences could include spermatogenesis failure, abnormal sperm motility, DNA fragmentation and male infertility, hypogonadism and 
erectile dysfunction (Sansone et al. 2021, Haghpanah et al. 2021). Though these considerations are crucial for male health, clinical studies on this problem are rare. The largest study on 74 men recovered from COVID-19 reported no detection of SARS-CoV-2 in urine, prostatic secretions or semen (Ruan et al. 2021).

\section{Hyperandrogenemia in women and COVID-19}

Polycystic ovary syndrome (PCOS) is a common female endocrinopathy, with a prevalence ranging from $6 \%$ to $20 \%$ and often accompanied, in addition to hyperandrogenemia, by insulin resistance and obesity, which are risk factors for coronavirus infection. To date, however, there are no data relating SARS-CoV-2 to PCOS in women (Morgante et al. 2021). Data relating to SARS-CoV-2 in PCOS women were published by Subramanian et al. (2021). They identified 21,292 women with a coded diagnosis of PCO/PCOS and randomly selected 78,310 age and general practice matched control women. The crude COVID-19 incidence was 18.1 and 11.9 per 1,000 person-years among women with and without PCOS, respectively. Age-adjusted Cox regression analysis suggested a $51 \%$ higher risk of COVID-19 among women with PCOS compared to women without PCOS (HR: 1.51 [95\% CI 1.27-1.80], $\mathrm{p}<0.001)$. Women with PCOS are at an increased risk of COVID-19 infection. On contrary the results of Yale et al. (2021) suggest that there is no evidence for an increased risk of COVID-19 infection, hospitalization, or mortality in women with acne vulgaris, PCOS, or hirsutism. Future studies on the course of COVID-19 in PCOS patients will need to take into account their phenotype, and will also need to distinguish the influences of hyperandrogenemia and obesity.

\section{Conclusions}

Findings from molecular biology on the mechanisms of SARS-CoV-2 penetration into host cells and clinical experience suggest that sex hormones, and androgens in particular, may play a role in the pathogenesis of this infection. Its course may be modified by both lower as well as higher androgen levels, depending on whether androgen-modified immunity or androgen-promoted viral entry into the cell predominates. Accumulated evidence suggests that there are links between high as well as low levels of testosterone in disease progression supporting the sex hormone role as a double-edged sword (Younis et al. 2021). We do yet not know whether the disease stages or other factors are determinant for the testosterone role in the disease course, and we have no evidence on whether coronavirus infections can adversely affect male fertility.

\section{Conflict of Interest}

There is no conflict of interest.

\section{Acknowledgements}

Supported by the Ministry of Health of the Czech Republic, RVO (Institute of Endocrinology - EU, 00023761).

\section{References}

AL-LAMI RA, URBAN RJ, VOLPI E, ALGBURI AMA, BAILLARGEON J: Sex hormones and novel corona virus infectious disease (COVID-19). Mayo Clin Proc 95: 1710-1714, 2020. https://doi.org/10.1016/j.mayocp.2020.05.013

CADEGIANI FA, GOREN A, WAMBIER CG: Spironolactone may provide protection from SARS-CoV-2: Targeting androgens, angiotensin converting enzyme 2 (ACE2), and renin-angiotensin-aldosterone system (RAAS). Med Hypotheses 143: 110112, 2020. https://doi.org/10.1016/j.mehy.2020.110112

CADEGIANI FA, LIM RK, GOREN A, MCCOY J, SITUM M, KOVACEVIC M, VAÑÓ GALVÁN S, SINCLAIR R, TOSTI A, WAMBIER CG: Clinical symptoms of hyperandrogenic women diagnosed with COVID-19. J Eur Acad Dermatol Venereol 15: e101-e104, 2021. https://doi.org/10.1111/jdv.17004

CATTRINI C, BERSANELLI M, LATOCCA MM, CONTE B, VALLOME G, BOCCARDO F: Sex hormones and hormone therapy during COVID-19 pandemic: Implications for patients with cancer. Cancers (Basel) 12: 2325, 2020. https://doi.org/10.3390/cancers12082325

DUTTA S, SENGUPTA P: SARS-CoV-2 and male infertility: Possible multifaceted pathology Reprod Sci 28: 23-26, 2021. https://doi.org/10.1007/s43032-020-00261-z 
GIAGULli VA, GUASTAMACCHIA E, MAGRONE T, JIRILlO E, LISCO G, DE PERGOLA G, TRIGGIANI V: Worse progression of COVID-19 in men: Is testosterone a key factor? Andrology 9: 53-64, 2021. https://doi.org/10.1111/andr.12836

GOREN A, MCCOY J, WAMBIER CG, VANO-GALVAN S, SHAPIRO J, DHURAT R, WASHENIK K, LOTTI T: What does androgenetic alopecia have to do with COVID-19? An insight into a potential new therapy. Dermatol Ther 33: e13365, 2020a. https://doi.org/10.1111/dth.13365

GOREN A, VAÑO-GALVÁN S, WAMBIER CG, MCCOY J, GOMEZ-ZUBIAUR A, MORENO-ARRONES OM, SHAPIRO J, SINCLAIR RD, GOLD MH, KOVACEVIC M, MESINKOVSKA NA, GOLDUST M, WASHENIK K: A preliminary observation: Male pattern hair loss among hospitalized COVID-19 patients in Spain - A potential clue to the role of androgens in COVID-19 severity. J Cosmet Dermatol 19: 1545-1547, 2020b. https://doi.org/10.1111/jocd.13443

GOREN A, WAMBIER CG, HERRERA S, MCCOY J, VAÑO-GALVÁN S, GIOIA F, COMECHE B, RON R, SERRANO-VILLAR S, RAMOS PM, CADEGIANI FA, KOVACEVIC M, TOSTI A, SHAPIRO J, SINCLAIR RJ: Anti-androgens may protect against severe COVID-19 outcomes: results from a prospective cohort study of 77 hospitalized men. J Eur Acad Dermatol Venereol 35: e13-e15, 2021c. https://doi.org/10.1111/jdv.16953

GRUBIC KEZELE T: Androgen-driven COVID-19 infection - is testosterone an enemy or a friend? Hormone Mol Biol Clin Invest 41: 20200027, 2020. https://doi.org/10.1515/hmbci-2020-0027

GURWITZ D. Angiotensin receptor blockers as tentative SARS-CoV-2 therapeutics. Drug Dev Res 81: 537-540, 2020. https://doi.org/10.1002/ddr.21656

HAGHPANAH A, MASJEDI F, ALBORZI S, HOSSEINPOUR A, DEHGHANI A, MALEKMAKAN L, ROOZBEH J: Potential mechanisms of SARS.CoV-2 action on male gonadal function and fertility. Current status and future prospects. Andrologia 53: e13883, 2021. https://doi.org/10.1111/and.13883

HOFFMANN M, KLEINE-WEBER H, SCHROEDER S: SARS-CoV-2 cell entry depends on ACE2 and TMPRSS2 and is blocked by a clinically proven protease inhibitor. Cell 181: 271-280, 2020. https://doi.org/10.1016/j.cell.2020.02.052

HUSSAIN AN, HUSSAIN F, HAS HMI SK: Role of testosterone in COVID-19 patients - A double-edged sword? Med Hypotheses 144: 110287, 2020. https://doi.org/10.1016/j.mehy.2020.110287

JONES AL, JAEGER B, SCHILD C: No credible evidence for links between 2D:4D and covid outcomes: A probabilistic perspective on digit ratio, ACE variants, and national case fatalities. Early Hum Dev 152: 105272, 2021. https://doi.org/10.1016/j.earlhumdev.2020.105272

KADIHASANOGLU M, AKTAS S, YARDIMCI E, ARAL H, KADIOGLU A: SARS-CoV-2 pneumonia affects male reproductive hormone levels: A prospective, cohort study. J Sex Med 18: 256-264, 2021. https://doi.org/10.1016/j.jsxm.2020.11.007

KARLBERG J, CHONG DSY, LAI WYY: Do men have a higher case fatality rate of severe acute respiratory syndrome than women do? Am J Epidemiol 159: 229-231, 2004. https://doi.org/10.1093/aje/kwh056

KLEIN EA, LI J, MILINOVICH A, SCHOLD JD, SHARIFI N, KATTAN MW, JEHI L: Androgen deprivation therapy in men with prostate cancer does not affect risk of infection with SARS-CoV-2. J Urol 205: 441-443, 2021. https://doi.org/10.1097/JU.0000000000001338

LA VIGNERA S, CANNARELLA R, CONDORELLI RA: Sex-specific SARS-CoV-2 mortality: among hormonemodulated ACE2 expression, risk of venous thromboembolism and hypovitaminosis D. Int J Mol Sci 21: 2948, 2020. https://doi.org/10.3390/ijms21082948

LUCAS JM, HEINLEIN C, KIM T: The androgen-regulated protease TMPRSS2 activates a proteolytic cascade involving components of the tumor microenvironment and promotes prostate cancer metastasis. Cancer Discov 4: 1310-1325, 2014. https://doi.org/10.1158/2159-8290.CD-13-1010

MANNING JT, FINK B: Understanding COVID-19: digit ratio (2D:4D) and sex differences in national case fatality rates. Early Hum Dev 146: 105074, 2020. https://doi.org/10.1016/j.earlhumdev.2020.105074

MCCOY J, WAMBIER CG, VANO-GALVAN S, SHAPIRO J, SINCLAIR R, RAMOS PM, WASHENIK K, ANDRADE M, HERRERA S, GOREN A: Racial variations in COVID-19 deaths may be due to androgen receptor genetic variants associated with prostate cancer and androgenetic alopecia. Are anti-androgens a potential treatment for COVID-19? J Cosmet Dermatol 19: 1542-1543, 2020. https://doi.org/10.1111/jocd.13455 
MONTOPOLI M, ZUMERLE S, VETTOR R, RUGGE M, ZORZI M, CATAPANO CV, CARBONE GM, CAVALLI A, PAGANO F, RAGAZZI E, PRAYER-GALETTI T, ALIMONTI A: Androgen-deprivation therapies for prostate cancer and risk of infection by SARS-CoV-2: a population-based study $(\mathrm{N}=4532)$. Ann Oncol 31: 1040-1045, 2020. https://doi.org/10.1016/j.annonc.2020.04.479

MORGANTE G, TROIA L, DE LEO V: Coronavirus disease 2019 (SARS-CoV-2) and polycystic ovarian disease: Is there a higher risk for these women? J Steroid Biochem Mol Biol 205: 105770, 2021. https://doi.org/10.1016/j.jsbmb.2020.105770

OKÇELIK S: COVID-19 pneumonia causes lower testosterone levels. Andrologia 53: e13909, 2021. https://doi.org/10.1111/and.13909

PACES J, STRIZOVA Z, SMRZ D, CERNY J: COVID-19 and the immune system. Physiol Res 69: 379-388, 2020. https://doi.org/10.33549/physiolres.934492

PAPADOPOULOS V, LI L, SAMPLASKI M: Why does COVID-19 kill more elderly men than women? Is there a role for testosterone? Andrology 9: 65-72, 2021. https://doi.org/10.1111/andr.12868

POZZILLI P, LENZI A: Commentary: Testosterone, a key hormone in the context of COVID-19 pandemic. Metabolism 108: 154252, 2020. https://doi.org/10.1016/j.metabol.2020.154252

RAMBHATLA A, BRONKEMA CJ, CORSI N, KEELEY J, SOOD A, AFFAS Z, DABAJA AA, ROGERS CG, LIROFF SA, ABDOLLAH F: COVID-19 Infection in men on testosterone replacement therapy. J Sex Med 18: 215-218, 2021. https://doi.org/10.1016/j.jsxm.2020.09.013

RASTRELLI G, DI STASI V, INGLESE F, BECCARIA M, GARUTI M, DI COSTANZO D, SPREAFICO F, GRECO GF, CERVI G, PECORIELLO A, MAGINI A, TODISCO T, CIPRIANI S, MASEROLI E, CORONA G, SALONIA A, LENZI A, MAGGI M, DE DONNO G, VIGNOZZI L: Low testosterone levels predict clinical adverse outcomes in SARS-CoV-2 pneumonia patients. Andrology 9: 88-98, 2021. https://doi.org/10.1111/andr.12821

ROWLAND SP, O'BRIEN BERGIN E: Screening for low testosterone is needed for early identification and treatment of men at high risk of mortality from Covid-19. Crit Care 24: 367, 2020. https://doi.org/10.1186/s13054-020$\underline{03086-\mathrm{Z}}$

RUAN Y, HU B, LIU Z, LIU K, JIANG H, LI H, LI R, LUAN Y, LIU X, YU G, XU S, YUAN X, WANG S, YANG W, YE Z, LIU J, WANG T: No detection of SARS-CoV-2 from urine, expressed prostatic secretion, and semen in 74 recovered COVID-19 male patients: A perspective and urogenital evaluation. Andrology 9: 99-106, 2021. https://doi.org/10.1111/andr.12939

SANSONE A, MOLLAIOLI D, CIOCCA G, LIMONCIN E, COLONNELLO E, VENA W, JANNINI EA: Addressing male sexual and reproductive health in the wake of COVID-19 outbreak. J Endocrinol Invest 44: 223-231, 2021. https://doi.org/10.1007/s40618-020-01350-1

SHI Y, WANG Y, SHAO C: COVID-19 infection: the perspectives on immune responses. Cell Death Differ 27: 1451-1454, 2020. https://doi.org/10.1038/s41418-020-0530-3

ŠIMKOVÁ M, VÍTKŮ J, KOLÁTOROVÁ L, VRBÍKOVÁ J, VOSÁTKOVÁ M, VČELÁK J, DUŠKOVÁ M: Endocrine disruptors, obesity, and cytokines - How relevant are they to PCOS? Physiol Res 69 (Suppl 2): S279-S293, 2020. https://doi.org/10.33549/physiolres.934521

STÁRKA L, DUŠKOVÁ M, POSPÍŠILOVÁ H, HILL M: Estradiol, obesity and hypogonadism. Physiol Res 69 (Suppl 2): S273-S278, 2020a. https://doi.org/10.33549/physiolres.934510

STÁRKA L, VÍTKŮ J, DUŠKOVÁ M: 11-Keto-testosterone and other androgens of adrenal origin. Physiol Res 69 (Suppl 2): S187-S192, 2020b. https://doi.org/10.33549/physiolres.934516

SUBRAMANIAN A, ANAND A, ADDERLEY N, OKOTH K, TOULIS KA, GOKHALE K, SAINSBURY C, O'REILLY MW, WIEBKE A, NIRANTHARAKUMAR K: Increased COVID-19 infections in women with polycystic ovary syndrome: a population-based study. Eur J Endocrinol 184: 637-645, 2021. https://doi.org/10.1530/EJE-20-1163

VAŠKU゚ A: Covid-19 infection and the host genetic predisposition: does it exist? Physiol Res 69: 511-514, 2020. https://doi.org/10.33549/physiolres.934504

WADMAN M: Sex hormones signals why virus hits men harder. Science 368: 1038-1039, 2020. https://doi.org/10.1126/science.368.6495.1038

WAMBIER C, GOREN A: Severe acute respiratory syndrome coronavirus 2 (SARS-CoV-2) infection is likely to be androgen mediated. J Am Acad Dermatol 83: 308-309, 2020a. https://doi.org/10.1016/j.jaad.2020.04.032 
WAMBIER CG, VAÑO-GALVÁN S, MCCOY J, GOMEZ-ZUBIAUR A, HERRERA S, HERMOSA-GELBARD Á, MORENO-ARRONES OM, JIMÉNEZ-GÓMEZ N, GONZÁLEZ-CANTERO A, FONDA-PASCUAL P, SEGURADO-MIRAVALLES G, SHAPIRO J, PÉREZ-GARCÍA B, GOREN A: Androgenetic alopecia present in the majority of patients hospitalized with COVID-19: The "Gabrin sign". J Am Acad Dermatol 83: 680-682, 2020b. https://doi.org/10.1016/j.jaad.2020.05.079

WAMBIER CG, GOREN A, VAÑO-GALVÁN S, RAMOS PM, OSSIMETHA A, NAU G, HERRERA S, MCCOY J: Androgen sensitivity gateway to COVID-19 disease severity. Drug Dev Drug Dev Res 81: 771-776, 2020. https://doi.org/10.1002/ddr.21688

WENHAM C, SMITH J, MORGAN R: COVID-19: The gendered impact of the outbreak. Lancet 395: 846-848, 2020. https://doi.org/10.1016/S0140-6736(20)30526-2

XU H, WANG Z, FENG C, YU W, CHEN Y, ZENG X, LIU C: Effects of SARS-CoV-2 infection on male sex-related hormones in recovering patients. Andrology 9: 107-114, 2021. https://doi.org/10.1111/andr.12942

YOUNIS JS, SKORECI K, ABASSI Z: The double edge sword of testosterone's role in the COVID-19 pandemic. Front Endocrinol (Lausanne) 12: 607179, 2021. https://doi.org/10.3389/fendo.2021.607179 